\title{
FIGHTING CORRUPTION WITH EDUCATION AND LAW
}

\author{
Muzaffar Syah Mallow \\ Associate Professor Dr., Faculty of Syariah \& Law, Universiti Sains Islam Malaysia (USIM), \\ Bandar Baru Nilai, Negeri Sembilan Darul Khusus, Malaysia, Email: \\ muzaffarsyah.mallow@yahoo.com
}

\begin{abstract}
Corruption is a hideous crime and dangerous disease which must be tackle immediately and effectively by all societies and in all countries. The effect of corruption is very severe not only to the involve individual to such crime but also to the entire society and country itself. In late January 2021, Malaysian were sadden with the dropping of the country Corruption Perceptions Index (CPI) ranking for the year 2020 released by the Transparency International (TI). Malaysia Corruption Perceptions Index (CPI) ranking for the year 2020 has drop to 57 among 180 countries compared to 51 which being achieved in 2019. At the same time, Malaysia scored through such index has also gone down to 51 points out of 100 compared to 53 points which being achieved in 2019. However, the fall of the country ranking and scored through the CPI has already been expected by many due to political instability which engulf the country and due to lack of effective measures taken by the country to deal with the issue of corruption itself. Corruption Perceptions Index (CPI) is an index published annually by Berlin-based Transparency International (TI) since 1995 which ranks countries by their perceived levels of public sector corruption, as determined by expert assessments and opinion surveys. If the country don't want their CPI ranking and number continue to drop in coming years, drastic measures must be identify and taken in order to make sure corruption will not continue to grow and become out of control problem. Amongst the ideal measures which can be taken to combat corruption is through education and legislation. Education is most important tool in combating corruption. Educational process need to be carry out constantly and effectively so that everybody able to comprehends about corruption and its effects. Beside education, having adequate legislations is also vital to combat corruption. Due to these, it is the objects of the paper to identify and examine further the role of education and legislation in combating corruption in the country. The outcome of this research paper would offer varieties of proposal to the government to give their focus over education and legislation in addressing with the issue of corruption.
\end{abstract}

Keywords: Corruption, education, and legislation

\section{INTRODUCTION}

Corruption is not only a crime but it is also a disease which effect all societies. Hardly, any countries in the world can claim that their societies are totally free from corruption. (Myjoyonline, 2013). To deal with corruption, each countries in the world has taken many steps to deal with the issue of corruption and to make sure corruption will not become a major problem which they need to deal with. Such steps includes combating corruption through education as well as through legislation. Most of the countries in the world will try their very best to make sure corruption level in their country remain low and under control. It is difficult to measures the level corruption which occur in each countries without reference to the Corruption Perceptions Index which been published annually by the Transparency International (TI). Transparency International (TI) is a nonprofit and non-governmental purpose is to take action to combat global corruption with civil societal anti-corruption measures and to prevent criminal activities arising from corruption. (Transparency International, 2021). The Corruption Perceptions Index or commonly known as CPI is an index published annually by Berlin-based Transparency International (TI) since 1995 which ranks countries by their perceived levels of public sector corruption, as determined by expert assessments and opinion surveys. (Transparency 
International, 2011). The CPI generally defines corruption as an abuse of entrusted power for private gain. (Ning He, 2016). The 2020 Corruption Perceptions Index (CPI), published in January 2021 ranks 180 countries on a scale from 100 (very clean) to 0 (highly corrupt) based on the situation between May 2019 and May 2020. (Transparency International, 2021). According the 2020 CPI list, countries like Denmark, Finland, New Zealand, Sweden, Singapore and Switzerland are perceived as the top 6 least corrupt nations in the world, ranking consistently high among international financial transparency, while the most perceived corrupt country in the world is Somalia, scoring 8-10 out of 100 since 2012. (Transparency International, 2017). Meanwhile, South Sudan is perceived as one of the most corrupt countries in the world due to constant social and economic crises, ranking an average score of 13 out of 100 in 2018. (Transparency International, 2018). As For Malaysia, the $2020 \mathrm{CPI}$ results indicate that Malaysia's score has deteriorated to 51 points in 2020 compared to 53 points in 2019. Malaysia's ranking in the CPI also deteriorated from 51 in 2019 to 57 in 2020 among the 180 countries surveyed. (Jo Timbuong, 2021). Though the dropping of the country score and ranking number is small to some, but such drop bring a very serious implication to everybody in the country. The country reputation in the eyes of the world also little bit been tarnish with such declined. Ever since the announced were made, many peoples in the country started to raised up their concern and want to government of the day to see such dropping as a serious matter and want the government of the day to take serious action to deal with it. (Malay Mail, 2021 and Malaysiakini, 2021).

It is difficult to identify the exact cause on the drop of the country Transparency International (TI) corruption index in 2020. However, Malaysia based Transparency International agency have highlighted few reasons which might become the potential reasons over the drop of such corruption index. Among the potential reasons includes: 1 . Institutional reforms in the country which have stalled. Among them are the Political Funding Bill which was to be tabled in Parliament by the last two governments but that did not happen. Also the Independent Police Complaints of Misconduct Commission (IPCMC) Bill was revised to a watered down version and a largely ineffective Independent Police Conduct Commission (IPCC) Bill. Further the separation of powers between the country Attorney General and Public Prosecutor is yet to be initiated by the government of the day, 2. Discharge not amounting to acquittal for some of those charged in high profile cases has given a negative perception on how the legal process is used, 3. Limited access to information on matters of public interest. For example, the compensation for cancelling the High Speed Rail project and the compensation paid as settlement by Goldman Sachs in the 1 Malaysia Development Berhad (1MDB) case is not disclosed to the public, 4. Continued cases of abuse of power and corruption by public official despite crack down by the country Malaysian Anti-Corruption Commission (MACC). For example, the recent arrest of immigration officers for issuing fake visas which remains a perennial problem, 5. Limited progress or public update on high profile cases eg. Wang Kelian human trafficking case, Sabah Water Scandal and Littoral Combat Ship, 6. Non Halal meat scandal reported to have operated with impunity for 40 years, 7. Government has yet to table Public Procurement Bill, and 8. Continued adverse reports on wrong doings and poor governance by government officials in the Auditor General's report which seems to go unpunished. (Transparency International Malaysia, 2021).

Before going further, it also worth to highlight several major cases involving corruption in the country. One of the most well-known and prominent cases of corruption within Malaysia and globally is that involving the 1 Malaysia Development Fund Bhd (1MDB). This corruption case is said to have involved the embezzlement of billions of US dollars, facilitated by the false declaration by officials. This included money laundering from accounts as well as bribery and gains from bond pricing. Although implications are mainly placed on Malaysia's businessmen and government officials, others from the United Arab Emirates (UAE) and Saudi Arabia have been implicated in the scandal. (The Guardian, 2015 and The Star, 2018).

Before $1 \mathrm{MDB}$ case, the largest corruption scandal in Malaysia was considered to be the Sabah State Water Corruption scandal. This case involved the siphoning of RM3.3 billion worth of federal allocations for state rural water projects from 2010 onwards to top department officials. This is the equivalent of over 759 million \$USD. The case arose due to complaints that water development project contracts were being distributed unfairly. The two suspects who were investigated included the Director of the Water Department and the Deputy Director. It is estimated that these two civil servants amassed a sum of almost RM115 million (24 million \$USD) due to their illicit activities. Such sums of money amassed due to the water department officials abusing their power to award contracts to 38 companies which were owned by their families or corrupt business officials. As a result, an investigation was carried out by the Malaysian Anti-Corruption Commission (MACC), who subsequently confiscated cash, luxury cars, jewellery and watches amounting to RM 114.5M. Prior to the previous 1 MDM corruption case, it was considered to be the largest amount of money confiscated by the MACC. (Simon Khoo, 2016 and Elton Gomez, 2016).

Very recently, the Malaysian Anti-Corruption Commission (MACC) has crippled a cartel which was accused 
of having monopolized the government projects. The MACC has arrested 7 suspects, including its 47 -yearold mastermind of the cartel. It is believed that the cartel, dubbed as a "project cartel", had monopolized a total of 345 tenders involving ministries and government agencies nationwide, where the projects are said to be worth RM3.8 billion. Quoting sources, the report said that the mastermind of the cartel controlled 150 companies that were being used to submit tender bids to ministries and government agencies. The suspect in this case has created different companies and employed individuals as company directors, but the fact is that he is the owner of these companies. The syndicate is said to have been operating since 2014 where the syndicate also received help from "insiders" from the ministries and government agencies to assist the mastermind's companies to submit and eventually secure their tender bids. The focus of the syndicate is on facility maintenance and development projects. What's more shocking is that the leader of a cartel that monopolized government contracts is said to own two helicopters, a yacht and over RM41 million worth of luxury cars and properties. In a raid at the leader's house, the MACC has also found RM3.5 million in cash. The suspect said to own some RM15.7 million in luxury cars, including several Mercedes-Benz models, a Range Rover and a Mustang GT. This is in addition to RM29 million worth of properties, including a bungalow, a shoplot and an office lot, that have been seized. (Ben Tan, 2021 and Robin Augustin, 2021).

\section{THE LAW AND PRACTICE IN MALAYSIA}

When it's come to the effort to combat corruption, it is very important for us first to note that Malaysia has become a signatory of the United Nations Convention against Corruption 2003 ("UNCAC") on December 9, 2003 and successfully ratified it on September 24, 2008. (United Nations Convention against Corruption, 2021). The UNCAC is a multilateral convention negotiated by members of the United Nations. It is the first global legally binding international anti-corruption instrument. Negotiated by member states of the United Nations (UN) it has been adopted by the UN General Assembly in October 2003 and entered into force in December 2005. The treaty recognise the importance of both preventive and punitive measures, addresses the cross-border nature of corruption with provisions on international cooperation and on the return of the proceeds of corruption. Under its 71 Articles, UNCAC requires that States Parties implement several anticorruption measures which may affect their laws, institutions and practices. These measures aim at preventing corruption, including domestic and foreign bribery, embezzlement, trading in influence and money laundering. The UNCAC covers many different forms of corruption, such as trading in influence, abuse of power, and various acts of corruption in the private sector. (United Nations Convention against Corruption, 2021). In addition to its obligation under the UN Convention, Malaysia is also a member of the Asian Development Bank/Organisation for Economic Co-operation and Development Anti-Corruption Action Plan for Asia and the Pacific and the Asia/Pacific Group on Money Laundering. All these international entries clearly indicate Malaysia is serious with international community commitment and desire to combat corruption.

There are a number of pieces of legislation in Malaysia which deal with corruption namely Penal Code [Act 574], Election Offences Act 1954 [Act 5], Customs Act 1967 [Act 235], Emergency (Essential Powers Ordinance) No. 22 of 1970, Anti-Money Laundering, Anti-Terrorism Financing and Proceeds of Unlawful Activities Act 2001 [Act 613], and Malaysian Anti-Corruption Commission Act 2009 [Act 694]. There are also various government directives and circulars produced by the Public Service Departments which can be utilised to combat corruption especially among the public servant like Public Officers (Conduct and Discipline) Regulations 1993, Service Circular No. 12 of 1967 (Anti-Corruption Agency Director's Investigation Report), Service Circular No. 17 of 1975 (National Investigation Bureau Investigation Report), Confidential General Circular No. 1 of 1984 (Investigation of Corruption Cases against Government Departments), Confidential General Circular No. 1 of 1985 (Integrity Vetting by Anti-Corruption Agency Malaysia), and other Service Circulars currently enforced.

The Malaysian Anti-Corruption Commission Act 2009 [Act 694] (hereinafter shall be known as "MACC Act 2009") which repealed the Anti-Corruption Act 1997 [Act 575] is the principal legislation dealing with corruption in the country. The MACC Act 2009 has the principal objective of promoting the integrity and accountability of public and private sector administration by constituting an independent and accountable anti-corruption body; and educating the public at large about corruption and its effects. According to the Malaysian Anti-Corruption Commission (MACC) corruption is the act of giving or receiving of any gratification or reward in the form of cash or in-kind of high value for performing a task in relation to his or her job description. (MACC, 2021). As for the definition of gratification itself, reference can be made to Section 3 of MACC Act 2009 gratification means (a) money, donation, gift, loan, fee, reward, valuable security, property or interest in property being property of any description whether movable or immovable, financial benefit, or any other similar advantage; (b) any office, dignity, employment, contract of employment or services, and agreement to give employment or render services in any capacity; (c) any payment, release, discharge or 
liquidation of any loan, obligation or other liability, whether in whole or in part; (d) any valuable consideration of any kind, any discount, commission, rebate, bonus, deduction or percentage; (e) any forbearance to demand any money or money's worth or valuable thing; (f) any other service or favour of any description, including protection from any penalty or disability incurred or apprehended or from any action or proceedings of a disciplinary, civil or criminal nature, whether or not already instituted, and including the exercise or the forbearance from the exercise of any right or any official power or duty; and (g) any offer, undertaking or promise, whether conditional or unconditional, of any gratification within the meaning of any of the preceding paragraphs (a) to (f). There are four main offences stipulated under the MACC Act 2009 for crime of corruption namely, soliciting ir receiving gratification (Bribe) [section 16 \& 17(a) MACC Act 2009], offering or giving gratification (Bribe) [section 17(b) MACC Act 2009], intending to deceive (False Claim) [Section 18 MACC Act 2009], and using office or position for gratification (Bribe) (Abuse of Power or Position) [Section 23 MACC Act 2009]. (MACC, 2021).

In the past MACC Act 2009 only has laws to take action against people who are involved in the corruption scandal. However beginning June, 12020 , MACC will be able to find companies guilty on top of the individuals involved. (New Straits Times, 2020). The reason behind this new law which is to encourage businesses to fight corruption, by placing measures to prevent corporate entities itself from taking part in any illegal dealings. It is a duty of everyone in the country to lodge a report over corruption. Failure for them to make such report has also been consider as a crime. Section 25 (1) of the MACC Act 2009 states "Any person to whom any gratification is given, promised, or offered, in contravention of any provision of this Act shall report such gift, promise or offer together with the name, if known, of the person who gave, promised or offered such gratification to him to the nearest officer of the commission or police officer". Section 25 (2) of the MACC Act 2009 states "Any person who fails to comply with subsection (1) commits an offence and shall on conviction be liable to a fine not exceeding one hundred thousand ringgit or to imprisonment for a term not exceeding ten years or to both". Any person who knows and fails to report an act of soliciting and obtaining of bribes is also committing an offence under Section 25 (3) and (4) of the MACC Act 2009. In order to encourage the public to combat corruption the MACC will make sure every information's given by the public will be protected and will not be disclosed to anyone under any circumstances. Witness to such crime will also be protected. The Malaysian government has enacted the Witness Protection Act 2009 [Act 696] and Whistleblower Protection Act 2010 [Act 711] on this regard. Witness Protection Act 2009 [Act 696] is a piece of legislation specially enacted in order to give protection to a threatened witness, before, during and after a trial, by a specially formed Witness Protection Unit, an agency under Prime Minister's Department. In August 2020, the Protection Division of the Prime Minister's Department is in the process of being rebranded as the Malaysian Witness Protection Agency (APSM). The rebranding exercise of the division, which was established in April 2010, is in line with its roles and responsibilities involving witness safety and the law. Apart from that, it could also indirectly assist the division to connect with the public and further facilitate cooperation with local and foreign authorities. (Malay Mail, August 12, 2020). The objective of the Witness Protection Act 2009 [Act 696] is to establish a programme for the protection and assistance of witnesses or participants and for other matters connected therewith. It's also cover high risk informer as a result of his assistance in a criminal investigation. Witness protection is usually required in trials against organized crime, where law enforcement sees a risk for witness to be intimidated by colleagues of defendants or accused person. Meanwhile, the objectives of the Whistleblower Protection Act 2010 [Act 711 ] includes: a) To combat corruption and other wrongdoings by encouraging and facilitating disclosures of improper conduct in the public and private sector; b) To protect persons making those disclosures from detrimental action; c) To provide for matters disclosed to be investigated and dealt with; and d) To provide for other matters connected therewith. Malaysia also has the Abduction and Criminal Intimidation of Witnesses Act 1948 [Act 191]. Besides the above mentioned three statutes, there are provisions in the country Criminal Procedure Code [Act 593] which provide for pleas in mitigation and plea bargaining. (Moktar Md Noor, 2011, pp. $81-86)$.

In order to enforce the mentioned law above, a specialised law enforcement body was created known as the Malaysian Anti-Corruption Commission ("MACC"). MACC was established in line with Section 4 of the MACC Act 2009. The functions of MACC is clearly provided under Section 7 of the MACC Act 2009 and are as follows:

(a) To receive and consider any report of the commission of an offence under this Act and investigate such of the reports as the Chief Commissioner or the officers consider practicable;

(b) To detect and investigate -

i. $\quad$ Any suspected offence under this Act; 
ii. Any suspected attempt to commit any offence under this Act; and

iii. Any suspected conspiracy to commit any offence under this Act;

(c) To examine the practices, systems and procedures of public bodies in order to facilitate the discovery of offences Malaysian Anti-Corruption Commission under this Act and to secure the revision of such practices, systems or procedures as in the opinion of the Chief Commissioner may be conducive to corruption;

(d) To instruct, advise and assist any person, on the latter's request, on ways in which corruption may be eliminated by such person;

(e) To advise heads of public bodies of any changes in practices, systems or procedures compatible with the effective discharge of the duties of the public bodies as the Chief Commissioner thinks necessary to reduce the likelihood of the occurrence of corruption;

(f) To educate the public against corruption; and

(g) To enlist and foster public support against corruption.

The MACC has extensive powers to investigate corruption and may order any person to appear before it to be examined. In addition, officers of the MACC are empowered by the MACC Act 2009 to have powers and immunity similar to that afforded to police officers in the performance of their duties; for example, powers of search and seizure of property. MACC has also been accorded powers of enforcement pursuant to 25 other pieces of legislation, which include areas of banking and financial transactions, company or society dealings and transactions, customs and smuggling activities, income tax, prison, and government supplies and election offences. MACC has also been given administrative powers to recommend disciplinary actions against public officials under various government directives and circulars highlighted above. Over the years, there have been improvement been suggested and made to the MACC Act of 2009 and the role of MACC itself. On September, 2020, the government of the day has agreed that the appointment of the Chief Commissioner of the Malaysian Anti-Corruption Commission (MACC) is to be done through Parliamentary votes. The MACC Chief Commissioner, Datuk Seri Azam Baki said the matter was decided at the meeting of the Special Cabinet Committee on Anti-Corruption. According to him the appointment for the MACC's top post will need two-thirds support from the Members of Parliament (MPs). (Malay Mail, September 3, 2020). This improvement been made in order to improve the role of MACC itself and the public perception towards the MACC as an independence body combating with corruption.

\section{FIGHTING CORRUPTION WITH EDUCATION AND LAW}

Due to the serious implication which corruption can bring to everyone, it is very important for everybody to play their role to combat corruption. The efforts of combating corruption can be carry out by several ways. The most common ways of combating with corruption is through education and by law. Having enough education and strong law in place is very crucial to combat corruption. These two ways can be seen as preventive steps to prevent anyone or entity to get involve with corruption. Combating corruption by way of education has been address internationally and at national level. A reference can be made to the United Nations Convention against Corruption 2003 under Article 7 (1) (d) where it states "Each State Party shall, where appropriate and in accordance with the fundamental principles of its legal system, endeavour to adopt, maintain and strengthen systems for the recruitment, hiring, retention, promotion and retirement of civil servants and, where appropriate, other non-elected public officials: d) That promote education and training programmes to enable them to meet the requirements for the correct, honourable and proper performance of public functions and that provide them with specialized and appropriate training to enhance their awareness of the risks of corruption inherent in the performance of their functions. Such programmes may make reference to codes or standards of conduct in applicable areas". Article 13 (1) (c) also states " Each State Party shall take appropriate measures, within its means and in accordance with fundamental principles of its domestic law, to promote the active participation of individuals and groups outside the public sector, such as civil society, non-governmental organizations and community-based organizations, in the prevention of and the fight against corruption and to raise public awareness regarding the existence, causes and gravity of and the threat posed by corruption. This participation should be strengthened by such measures as: (c) Undertaking public information activities that contribute to non-tolerance of corruption, as well as public education programmes, including school and university curricula". (United Nations Convention against Corruption, 2021). The Malaysian Anti-Corruption Commission Act 2009 [Act 694] also highlight within its provisions about the element of education in combating with corruption. Its states under Section 7 (f) and (g) that among the functions of the Malaysian Anti-Corruption Commission ("MACC") are to educate the public against corruption and to enlist/recruit and foster public support in the country against corruption. 
According to the MACC, the main focus of education activities is continuously disseminating anti-corruption information to all levels of society, while raising public awareness and confidence in the corruption prevention effort in Malaysia. Education programmes and activities are conducted nationwide through the MACC Community Education Division (headquarters) and the Community Education Unit of MACC State Offices (state level). The effectiveness of community programmes and activities are measured using the Corruption Prevention Action Effectiveness Perception Study conducted by MACC annually. The results of this study are used to regularly improve and strengthen the education strategy, approach and initiatives. MACC utilises two main approaches in educating the public on corruption, namely face-to-face programmes and dissemination of message via media channels. The implementation of education activities by MACC is to be targeted to the following groups namely, public agencies, private sectors and government-linked companies (GLC) as well non-governmental organizations (NGOs) and political organization. Examples of activities conducted for these particular groups include Corruption-Free Pledge (IBR), seminar, forum, talks, workshops, On-the-ground programmes, visit to MACC and others. Besides that the MACC also conducted educational activities and programs to university or higher learning institution students. The anti-corruption activities and programmes involving students from public and private higher learning institutions are coordinated by the University Branch, MACC Community Education Division. MACC also conducted educational activities and programs to students in secondary and primary school. The anti-corruption activities and programmes involving primary and secondary school students are coordinated by the School Branch, MACC Community Education Division. Among the main programme organised by MACC is Anticorruption Heroes (Wira Antirasuah - WAR). This programme, which began in 2014, is a joint effort between MACC and the Malaysian Ministry of Education (MOE). (MACC, 2021).

Though the international convention, national law and agency did address the need over education to combat corruption, aggressive step need to be carry out more by the relevant agency like the MACC along with other relevant departments and agencies in order to educate the society over the issue of corruption. The dropping of the country Corruption Perceptions Index (CPI) in 2020 and the emergence of new high profile cases involving corruption in the country clearly indicate to us that all the efforts which been undertaken to educate our people over the issue of corruption is not enough. The Integrity Institute of Malaysia (IIM) has conducted a study in 2017 on the Students' Perception of Corruption and found that one in every three participants (35.8\%) thinks that it is not corruption if a person receives gifts (in the form of money, goods or service) in exchange for another service rendered. Here are some key findings from the survey: $37.3 \%$ of the respondents assumed that submitting claims for fully-sponsored outstation duties was not wrong. $20.6 \%$ of the respondents considered direct involvement in the process of appointing family members to fill vacancies in their department is a permissible act. $28.1 \%$ of the respondents thought that it was not an offence for them to take company-owned properties or items, including pen drives, printer ink or papers for personal use. (Anis Yusal Yusoff \& Zarina Mohamad Amin, 2017). According to the revelation made by the MACC in 2017, it has found that about 16 per cent of students in higher institutions of learning (IPT) in the country are willing to accept bribes if they have the opportunity and power to do so. The figure was obtained from a Corruption Prevention Action Effectiveness Perception Study among students by MACC. The figure is worrying because only 10.7 percent of the students in 2015 and 11.3 percent in 2014 had stated their willingness to receive bribes. The study also found 18.2 percent of the students were prepared to give bribes to avoid action, an increase of 0.8 percent from 17.4 percent in 2015 . The study also found the number of students who were willing to report corruption cases had dropped to 66.3 percent compared to 74.1 percent in 2015 and 74.9 in 2014. (Bernama, 2017).

These statistic is a worrying trend for us. If we allow these to continue, it can certainly hamper all our efforts to combat corruption. The researcher would like to propose to the government to look into the matter deeply. The government should set up a special committee at national level to identify the root cause of the problem and find possible solution to deal with the issue. The special committee should consist relevant ministries, departments and agencies as well as expert in the field involving the issue of corruption. The time has also come for the government to re-visit and re-analyse the existing academic curricula in our schools and universities. Our academic curricula in schools and universities should consists topic specifically addressing the issue of corruption. Our students in schools and universities must be expose at early age about the issue of corruption, the definition and forms of corruption, causes and effects of corruption as well as steps to combat corruption. Our students in schools and universities should have basic idea about corruption and a clear understanding why it should be avoided and prevented. (Free Malaysia Today, September 2, 2020). At the same time, the focus on education should not be restricted to pupils in the educational institutions only. Every individual within the society should be expose and educate over the issue. More efforts need to be done to expose and educate our society over the issue of corruption. This can be effectively by using mass media like Television, Radio, as well as the modern platform through internet. Such educational efforts must 
be carry out regularly forever. The MACC as the leading agency in combating with corruption in the country must lead the effort to expose and educate the public about anti-corruption efforts, including corruption prevention and the importance of practising good governance through integrity. (Borneo Post, 2016). Creative ways need to find to educate our people especially our youth to combat corruption. For example, in April 2021, the Malaysian Youth Council (MBM) had launched "Belia Rasuah Busters" with the prime target to educate the youth and community to fight corruption. (Malay Mail, 2021).

Besides having education, it is equally important to have effective laws in place to combat corruption. The government should examine all the concerns which been raised by the Malaysia based Transparency International agency on the issue over corruption which been highlighted above. The government should carry out more reforms within its existing administrative and enforcement institutions in order to combat with the issue of corruption. The government must also guaranteed the present of free media in the country if we want to combat with the issue of corruption more effectively. (Malaysiakini, 2021). All the allegation which been raised which touch the integrity aspect of any of our existing institutions should receive serious attention by the government and be investigated properly and immediately. (Muzaffar Syah Mallow and Syed Saddiq Syed Abdul Rahman, 2021).

\section{REFERENCE LIST}

Anis Yusal Yusoff \& Zarina Mohamad Amin. (2017). Laporan hasil kajian persepsi mahasiswa mengenai rasuah di Malaysia. Institut Integriti Malaysia. http://integriti.my/wp-content/uploads/2017/07/Hasilkajian-Mahasiswa.pdf. Retrieved on May 22, 2021.

Anti-corruption module to be taught in schools, says MACC chief. (September 2, 2020). https://www.freemalaysiatoday.com/category/nation/2020/09/02/anti-corruption-module-to-be-taughtin-schools-says-macc-chief/. Retrieved on May 21, 2021.

Augustin, Robin. (April 5, 2021). MACC cripples cartel with monopoly over hundreds of govt jobs. https://www.freemalaysiatoday.com/category/nation/2021/04/05/macc-cripples-cartel-with-monopolyover-hundreds-of-govt-jobs/. Free Malaysia Today. Retrieved on May 21, 2021.

Azam Baki: Appointment of MACC chief to be done through Parliamentary votes. https://www.malaymail.com/news/malaysia/2020/09/02/azam-baki-appontment-of-macc-chief-to-bedone-through-parliamentary-votes/1899559. Malay Mail. Retrieved on May 21, 2021.

Corruption Perceptions Index. (January 28, 2021). https://www.transparency.org/en/cpi/2020/index/nzl. Retrieved on May 21, 2021.

Corruption Perceptions Index. (February 21, 2018). https://www.transparency.org/en/news/corruptionperceptions-index-2017. Retrieved on May 21, 2021.

Corruption Perceptions Index. (January 29, 2019). https://www.transparency.org/en/cpi/2018/index/dnk. Retrieved on May 21, 2021.

Gomez, Hilton. (October 5, 2016). Biggest cash seizure made following arrest of Sabah officials in MACC probe. http://www.theborneopost.com/2016/10/05/biggest-cash-seizure-made-following-arrest-ofsabah-officials-in-macc-probe/. Retrieved on May 21, 2021.

He, Ning (1 June 2016). "Rethinking the Causes of Corruption: Perceived Corruption, Measurement Bias, and Cultural Illusion". Chinese Political Science Review. 1 (2): 268-302. https://link.springer.com/article/10.1007/s41111-016-0024-0. Retrieved on May 21, 2021.

Khoo, Simon. (October 4, 2016). Two Sabah agency top officers nabbed, RM3mil seized. https://www.thestar.com.my/news/nation/2016/10/04/two-top-sabah-agency-officer-corruption/. Retrieved on May 21, 2021.

MACC stepping up efforts to educate public on corruption. (April 23, 2016). https://www.theborneopost.com/2016/04/23/macc-stepping-up-efforts-to-educate-public-oncorruption/. Retrieved on May 22, 2021.

MACC: Sixteen pct of students willing to accept bribes. https://www.malaysiakini.com/news/379706. Bernama Online. Retrieved on May 22, 2021. 
Malaysian Youth Council launches 'Belia Rasuah Buster' to educate youth, community to fight corruption. (April 26, 2021). https://www.malaymail.com/news/malaysia/2021/04/26/malaysian-youth-councillaunches-belia-rasuah-buster-to-educate-youth-commu/1969597. Retrieved on May 22, 2021.

Malaysian Anti-Corruption Commission (MACC). (2021). https://www.sprm.gov.my/index.php?id=21\&page_id=75\&articleid=478. Retrieved on May 21, 2021.

Malaysia's drop in TI Corruption Index must be taken seriously, says Lee Lam Thye. (February 1, 2021). https://www.malaymail.com/news/malaysia/2021/02/01/malaysias-drop-in-ti-corruption-index-must-betaken-seriously-says-lee-lam/1945976. Malay Mail Online. Retrieved on May 21, 2021.

Malaysian taskforce investigates allegations $\$ 700 \mathrm{~m}$ paid to PM Najib. (July 6, 2015). https://www.theguardian.com/world/2015/jul/06/malaysian-task-force-investigates-allegations-700mpaid-to-pm-najib. The Guardian Online. Retrieved on May 21, 2021

Mokhtar Md NoOr. (November, 2011). Securing Protection \& Cooperation of Witnesses and Whistle-Blowers. Fourth Regional Seminar on Good Governance for Southeast Asian Countries. https://www.unafei.or.jp/publications/pdf/GG4/Fourth_GGSeminar_all.pdf. Retrieved on May 21, 2021.

MP saran kebebasan media untuk perangi rasuah. (January 13, 2021). https://www.malaysiakini.com/news/561107. Retrieved on May 22, 2021.

MP moots independent media to combat corruption. (January 31, 2021). https://www.malaysiakini.com/news/561104. Retrieved on May 21, 2021.

Muzaffar Syah Mallow and Syed Saddiq Syed Abdul Rahman. (April 1, 2021). Crucial to probe existence of cartel in police force. https://www.thesundaily.my/opinion/crucial-to-probe-existence-of-cartel-in-policeforce-CC7477985. The Sun Daily Online. Retrieved on May 21, 2021.

New Straits Times. (May 21, 2020). M'sia's corporate liability provision to take effect on June 1. https://www.nst.com.my/news/government-public-policy/2020/05/594350/msias-corporate-liabilityprovision-take-effect-june-1. Retrieved on May 21, 2021.

No country is free from corruption - Former Auditor-General. (October, 3 2013). https://www.myjoyonline.com/no-country-is-free-from-corruption-former-auditor-general/. Retrieved on May 21, 2021.

Protection Division under PM's Dept to be rebranded as Malaysian Witness Protection Agency. https:/www.malaymail.com/news/malaysia/2020/08/12/protection-division-under-pms-dept-to-berebranded-as-malaysian-witness-pro/1893362. Malay Mail Online. Retrieved on May 21, 2021.

Tan Ben. (April 5, 2021). MACC cripples cartel with monopoly over RM3.8b worth of government tenders. https://www.malaymail.com/news/malaysia/2021/04/05/macc-cripples-cartel-with-monopoly-overrm3.8b-worth-of-government-tenders/1963990. Malay Mail Online. Retrieved on May 21, 2021.

Timbuong, Jo. (January, 28, 2021). Malaysia drops six spots in worldwide corruption perceptions index ranking. The Star Online. https://www.thestar.com.my/news/nation/2021/01/28/malaysia-drops-sixspots-in-worldwide-corruption-perceptions-index-ranking. Retrieved on May 21, 2021.

Transparency International (2011). “Corruption Perceptions Index”. Transparency International. Transparency International. Archived from the original on 13 December 2011. https://web.archive.org/web/20111213111904/http://www.transparency.org/policy_research/surveys_in dices/cpi. Retrieved on May 21, 2021.

Transparency International (2021). "Our impact - Transparency International”. https://www.transparency.org/en/our-impact. Retrieved on May 21, 2021.

Transparency International Malaysia (2021). "Corruption Perceptions Index". https://transparency.org.my/pages/news-and-events/press-releases/corruption-perceptions-index2020-1. Retrieved on May 21, 2021.

United Nations Convention against Corruption. (2021). https://www.unodc.org/unodc/en/corruption/uncac.html. Retrieved on May 21, 2021.

US DOJ says pursuing investigations related to Malaysia's 1MDB. (May 22, 2018). https://www.thestar.com.my/business/business-news/2018/05/22/us-doj-says-pursuing-investigationsrelated-to-malaysias-1mdb/. Retrieved on May 21, 2021 